\title{
Analysis of sense of places effect on tourist's length of stay in the Khota Baru cultural heritage zone
}

\author{
Nik Mohamad Aizat Nik Mohd Adib
}

International Islamic University Malaysia, Kuala Lumpur, Malaysia. Nikaizat86@gmail.com

Syakir Amir Ab. Rahman

International Islamic University Malaysia, Kuala Lumpur, Malaysia.

syakiramir@iium.edu.my

\begin{abstract}
Heritage and cultural tourism are part of the tourism industry that must be maintained sustainability. Therefore heritage tourism destinations must be able to carry a "sense of place" as its focus. A sense of place is essential in attracting tourists to visit heritage sites for a long time. This article aims to assess the relationship between the Sense of Place between tourists, domestic and international, and the length of stay in the Kota Bharu Cultural Heritage Zone. A total of 445 tourists participated as respondents by filling out a questionnaire survey. At the same time, data analysis was carried out using One way ANOVA. The results showed that the Sense of Place in the Kota Bharu Cultural Heritage Area affects tourists' length of stay with eight correlated scales. Those eight scales are authenticity, historical value, distinction, harmony, maintainability, and cleanliness. This study also finds several important implications for local governments and tourism practitioners in maintaining a tourism destination's economic and social attributes. This study is expected to serve as the basis for future studies related to the design of urban areas and other heritage tourism sites.
\end{abstract}

Keywords: the sense of place, heritage site, tourist length of stay

\begin{abstract}
Abstrak
Wisata warisan dan budaya merupakan bagian dari industri pariwisata yang harus dijaga keberlanjutannya. Untuk memastikan hal tersebut, destinasi wisata warisan harus mampu membawa "sense of place" sebagai fokusnya. Sense of place menjadi penting untuk menarik wisatawan mengunjungi situs warisan dalam jangka waktu yang lama. Artikel ini bertujuan untuk menilai hubungan antara Sense of Place antara wisatawan, baik domestik maupun internasional, dengan lama tinggal di Zona Cagar Budaya Kota Bharu. Sejumlah 445 wisatawan berpartisipasi sebagai responden dengan mengisi survei kuesioner, sedangkan analisis data dilakukan dengan One way ANOVA. Hasil penelitian menunjukkan bahwa sense of place di Kawasan Cagar Budaya Kota Bharu mempengaruhi lama menginap wisatawan dengan delapan skala yang berkorelasi yaitu keaslian, nilai sejarah, kekhasan, harmonis, keterawatan, dan kebersihan. Studi ini juga menemukan sejumlah implikasi penting bagi pemerintah daerah dan praktisi pariwisata, dalam mempertahankan atribut ekonomi dan sosial suatu destinasi pariwisata. Studi ini diharapkan dapat berperan sebagai dasar kajian di masa yang akan datang terkait disain kawasan perkotaan dan situs pariwisata warisan lainnya.
\end{abstract}

Kata kunci: sense of place, situs warisan, lama inap wisatawan

Received: 2019-04-29 | Accepted: 2020-08-09 | DOI: 10.29080/eija.v6i1.902 | Page: 23 - 32

\section{EMARA: Indonesian Journal of Architecture \\ http://jurnalsaintek.uinsby.ac.id/index.php/EIJA}

This article is open access distributed under the terms of the Creative Commons Attribution ShareAlike 4.0 International License, which permits unrestricted use, distribution, and reproduction in any medium provided the original work is properly cited. 


\section{Introduction}

The contemporary pattern has seen tourism as one of the main contributors to one nation's development in economy, society, and environment. Tourism has many types, including heritage tourism. In ensuring heritage tourism, the countries with rich culture and physical heritage, including tangible and intangible values, concern the sense of place. A sense of place as a broad concept is vital in ensuring tourists visit the heritage site, thus ensuring heritage tourism in a particular place. The vibrant heritage tourism in terms of social, economy, and environment will lead to sustainable tourism, leading to sustainable development.

A sense of place is a personal emotion of the place derived from our past experienced in the relation of the social, economic, and culture (Hauge, 2007). A sense of place, which comprises place identity, place attachment, and place dependent often linked with the attitude, experience, and perception of people towards a particular place (McCunn \& Gifford, 2014). It is also defined by Tan et al. (2018) that a sense of place is a bonding that connects individuals and their meaningful places. Bonding and emotion associated with individual perceptions of their identity regarding the physical environment become the central concept of sense of place (McCunn \& Gifford, 2014; Pretty et al., 2003). In contrast, the heritage is far from relics and ancient practice from the past. It is all about the community's past and present that considers valuable, which intends to pass it to future generations (Idrus et al., 2010). Heritage also something that cannot be recreated. Heritage site comprises of unique culture or significant physical structure. The relation between sense of place and heritage site happened when the people have a close personal feeling for the heritage site. They will come again, thus ensuring vibrant and sustainable tourism in that place.

Length of stay signifies the amount of time that the tourist spent at a given destination and one of the essential tourism demand variables (Santos et al., 2014). Researchers agree that length of stay had become the critical element to generate tourism revenue and expenditure due to its crucial importance variable for any tourism destination (Alén et al., 2014; Barros \& Machado, 2010; Kazuzuru, 2014; Thrane \& Farstad, 2012). Length of stay is essential to sustainable tourism research since it is useful in tourist forecasting, demand, and local resource consumption. Those use highlighted as an essential issue in the context of carrying capacity analysis (de Menezes et al., 2008). Length of stay is critical to the marketing policies design, associated with higher occupancy rates and revenue streams, to understand the impact of tourists' demand on the travel and hospitality industries. Furthermore, studies using the duration or length of stay as tourism variables are rare (Barros \& Machado, 2010). To attract tourists in prolonging their stay in the historical site, that particular site must preserve its unique and authentic identity as well as its sense of place.

Since the sense of place related to tourists' length of stay, the research on Kelantan's heritage site associated with a sense of place and tourist's length of stay has been conducted. The number of tourists visits to Kelantan was around 5 million people in 2017, which recorded the lowest percentage among other states in Malaysia (Kelantan Tourism Information Centre, 2017). Few claim that this result due to the lack of sense of place and 
authenticity with the Kelantan cultural heritage site. Until recently, a limited study has been conducted to assess and validate a sense of place. Relationship with tourism area, mainly historical-cultural places in Kelantan, whether the tourist intends to prolong their stay is significant with the authenticity of historical places in Kelantan. Therefore, this paper aims to analyze the relationship between sense of place among tourists' intention to prolong their stay in Kota Bharu Cultural Heritage Zone.

\section{Methods}

A questionnaire survey approach was chosen for this study conducted in the area of Kota Bharu Cultural Heritage Zone. The questionnaire survey consists of closedended questions with ordered choices that require the respondent to examine each possible response independent of the other choices. The choices form a continuum of responses, such as those provided by Likert scales and numerical ranges. The range is from strongly Disagree to Agree strongly. After the survey process, it was followed by the statistical analysis method of One-Way Anova.

The study area is in Kota Bharu Cultural Heritage Zone or 'Zon Warisan Budaya' that is situated in Kota Bharu district along the Kelantan River. In 1991, The Kota Bharu Municipal Council-Islamic City (MPKB-BRI) inaugurated it as a cultural heritage zone. The consideration is that the zone has various kinds of museums and former iconic and unique royal buildings inherited from centuries ago. The heritage zone covers an area of 12 hectares. The zone itself is based on the original location of the royal palace and government buildings of Kota Bharu in the year 1844. According to Kota Bharu Local Plan 2020, the zone itself is under a particular area plan of cultural heritage.
Kota Bharu Cultural Heritage's buildings can be categorized into the royal palace, museum, monument, square, mosque, hotel, restaurant, shophouses, shopping, and facility. The zone gazette as a cultural heritage zone, it has been a prime tourism destination in Kota Bharu. The respondents are among domestic and international tourists who visited the zone during the data collection period.

The sample size was taken based on Yamane's formula. It can be used to determine the minimal sample size for a given population size and, therefore, be considered suitable for determining an appropriate sample size (Botes, 2009; Mora \& Kloet, 2010). In this study, 5,321,957 tourists were visiting Kelantan in 2017. Thus, by using the total number of tourists visiting Kelantan as the population size $(\mathrm{N}=5,321,957)$ with a $95 \%$ confidence level $(\mathrm{P}=0.5)$, the estimated sample size reached 400 . This number is the lowest acceptable number of responses to maintain a $95 \%$ confidence level. Therefore, the study prepared 500 units of a questionnaire survey to be distributed. The sampling method used for this study is a simple random sampling that every sampling unit has an equal chance of being chosen (Alvi, 2016; Shalab, 2019). This method avoids choosing a case of element more than once. The randomly selected sample is then called representative for the entire population (Ahmed, 2009; Frerichs, 2008; Mora \& Kloet, 2010).

The tourist's sense of place is measured based on Bott's (2000) set of psychometric scales. This study involves ten scales, including the built environment, inherent socio-cultural, transactional socio-cultural, significance, memory, aesthetic, purposive, informational, well-being, and character scale. This set of psychometric scale has 
been used by Raadik-Cottrell (2010) and Counted (2019).

The sample population for this research was composed of tourists who visited the Kota Bharu Cultural Heritage Zone in September 2019. The survey was conducted over three months, from 1 September to 31 December 2019, at seven different most visited places in the zone. The survey period's determination takes into account the conditions in September 2019 , which have four days off in a week in three consecutive weeks. It continued with the end of year school holiday started from 22 November to 31 December.

Those conditions will cause a peak of tourists to visit the zone, as mentioned by Kelantan's museum official. Respondents were approached and informed about the survey's purpose in advance before they were given the questionnaire. Data were collected at seven different places, including four museums, which are Istana Jahar, Istana Batu, War Museum, and Islamic museum. Two squares, which are Kota Sultan Ismail and Muhammadi square, and Nasi Ulam Cikgu restaurant.

\section{Result and Discussion}

The initial sample consisted of 500 questionnaires, with 55 of them did not complete the surveys. Therefore, the data from 445 respondents were analyzed in this study.

\section{Respondents socio-demographic profile}

The respondents' age was dominated by the age group 21-30 years (41.8\%), and the age group of 61 years and over was the smallest group of respondents (0.4\%). Most of the respondent's marital status was single $(66.1 \%)$. It was followed by married $(30.1 \%)$, divorced $(2.2 \%)$, and widowed $(1.6 \%)$ and regarding occupational professions, dominated by students $(44.7 \%)$, government servants (31\%), and private employees (20\%). Most of the respondents, with $90.8 \%$, reported that they were Malaysian, whereas $9.2 \%$ of the respondents were international travelers. In terms of education level, $78.2 \%$ of the respondents had a university education level; $42.7 \%$ of the respondents had a diploma education, $27.2 \%$ had bachelor's degree education, and $8.3 \%$ had post-graduate education. $16.8 \%$ of the respondents had a secondary school education. No respondent in the research study was at the primary level or below. The result shows the relatively high educational attainment of the respondents (see appendix 1).

\section{Respondents trip profile}

In the category of the first-time visit to Kota Bharu Cultural Heritage Zone, 60.2\% of respondents have visited the zone in the past. In comparison, $39.8 \%$ of the respondents did not have previous experience with the area. Furthermore, respondents' length of stay showed that $53.7 \%$ of the respondents had stayed 2 to 4 days. It was followed by respondents who stayed five to seven days (25.2\%), respondents who stayed eight days or more $(11.0 \%)$, and respondents who stayed one day only (10.1\%) (see appendix 2).

\section{Tourist perception of the sense of place}

The Built Environment Scale indicates two items that significantly different in the length of stay in Kota Bharu. 'Building color scale' $(\mathrm{f}(3,441)=2.886, \mathrm{p}<0.05)$ and 'materials which fit the setting' (f $(3,441)$ $=6.348, \mathrm{p}<0.05)$ (see table 1$)$. The other item shows no significant differences to the length of stay of respondents in Kota Bharu and scheduled to visit Kota Bharu Cultural Heritage Zone, 'has attractive buildings' ( $\mathrm{f}(3,441)=0.248, \mathrm{p}>0.05)$. The sense of place referring to the Built Environment in Kota Bharu Cultural Heritage Zone influences the tourist's decision to stay longer in the zone. 
Table 1. One-way ANOVA test on the length of stay

\begin{tabular}{|c|c|c|c|c|}
\hline Components & df & F - value & P-value & Significant \\
\hline \multicolumn{5}{|l|}{ Built Environment Scale } \\
\hline Building color & 3,441 & 2.886 & 0.035 & yes \\
\hline Materials which fit the setting & 3,441 & 6.348 & 0.000 & yes \\
\hline Has attractive buildings & 3,441 & 1.381 & 0.248 & no \\
\hline Character Scale & $\mathrm{df}$ & $\mathrm{F}$ & Sig. value & Significant \\
\hline Clean & 3,441 & 2.111 & 0.098 & no \\
\hline Alive & 3,441 & 1.308 & 0.271 & no \\
\hline Peaceful & 3,441 & 6.797 & 0.000 & yes \\
\hline Distinctive & 3,441 & 2.345 & 0.072 & no \\
\hline Harmonious & 3,441 & 4.133 & 0.007 & yes \\
\hline Balanced & 3,441 & 6.027 & 0.000 & yes \\
\hline Well-maintained & 3,441 & 2.512 & 0.058 & no \\
\hline Simple & 3,441 & 3.240 & 0.022 & yes \\
\hline Spacious & 3,441 & 3.947 & 0.008 & yes \\
\hline Open & 3,441 & 5.161 & 0.002 & yes \\
\hline Inherent Socio-Cultural Scale & $\mathrm{df}$ & $\mathrm{F}$ & Sig. value & Significant \\
\hline Historic & 3,441 & 4.239 & 0.006 & yes \\
\hline Authentic & 3,441 & 2.831 & 0.038 & yes \\
\hline Has the spirit of people & 3,441 & 3.050 & 0.028 & yes \\
\hline Fits within the broader context Kota Bharu & 3,441 & 3.160 & 0.025 & yes \\
\hline Support the function of Kota Bharu & 3,441 & 3.201 & 0.023 & yes \\
\hline Feel the sense of history & 3,441 & 3.378 & 0.018 & yes \\
\hline Transactional Sociocultural Scale & $\mathrm{df}$ & $\mathrm{F}$ & Sig. value & Significant \\
\hline Offers a sense of belonging & 3,441 & 4.180 & 0.006 & yes \\
\hline Provide opportunities for interaction with others & 3,441 & 4.009 & 0.008 & yes \\
\hline Civility & 3,441 & 4.115 & 0.007 & yes \\
\hline Generates respects for the individual & 2,442 & 5.116 & 0.006 & yes \\
\hline Has a distinct energy & 3,441 & 3.714 & 0.012 & yes \\
\hline Feel a part of the community & 3,441 & 5.316 & 0.001 & yes \\
\hline Significance Scale & $\mathrm{df}$ & $\mathrm{F}$ & Sig. value & Significant \\
\hline Meaningful & 3,441 & 4.567 & 0.005 & yes \\
\hline Significant & 3,441 & 4.549 & 0.004 & yes \\
\hline Interesting & 3,441 & 3.446 & 0.017 & yes \\
\hline Valuable & 3,441 & 3.394 & 0.018 & yes \\
\hline Memory Scale & $\mathrm{df}$ & $\mathrm{F}$ & Sig. value & Significant \\
\hline Familiar & 3,441 & 3.079 & 0.027 & yes \\
\hline Well-known & 3,441 & 1.894 & 0.130 & no \\
\hline Memorable & 3,441 & 1.433 & 0.232 & no \\
\hline Feel a sense of connection & 3,441 & 3.188 & 0.024 & yes \\
\hline Feel i know it well & 3,441 & 2.460 & 0.062 & no \\
\hline Feel a sense of nostalgia & 3,441 & 3.066 & 0.028 & yes \\
\hline Aesthetic Scale & $\mathrm{df}$ & $\mathrm{F}$ & Sig. value & Significant \\
\hline Beautiful & 3,441 & 4.113 & 0.007 & yes \\
\hline Aesthetically pleasing & 3,441 & 4.287 & 0.005 & yes \\
\hline Pleasing to look at & 3,441 & 2.011 & 0.112 & No \\
\hline Generates a positive sensory experience & 3,441 & 4.723 & 0.003 & Yes \\
\hline Feel a sense of awe & 3,441 & 2.665 & 0.047 & Yes \\
\hline Feel a sense of appreciation & 3,441 & 4.585 & 0.004 & Yes \\
\hline Purposive Scale & $\mathrm{df}$ & $\mathrm{F}$ & Sig. value & Significant \\
\hline Meets my expectations historical site & 3,441 & 2.227 & 0.084 & No \\
\hline Support the role at a historical site & 3,441 & 3.163 & 0.024 & Yes \\
\hline Informational Scale & $\mathrm{df}$ & $\mathrm{F}$ & Sig. value & Significant \\
\hline Understandable & 3,441 & 3.422 & 0.017 & Yes \\
\hline Provides a sense of direction & 3,441 & 3.362 & 0.019 & yes \\
\hline Has a distinct landmark & 3,441 & 3.395 & 0.018 & yes \\
\hline Is easy to find the way around in & 3,441 & 4.932 & 0.002 & yes \\
\hline Makes way-finding seem intuitive & 3,441 & 4.548 & 0.004 & yes \\
\hline Provides info & 3,441 & 3.560 & 0.014 & yes \\
\hline Well-being Scale & $\mathrm{df}$ & $\mathrm{F}$ & Sig. value & Significant \\
\hline Safe & 3,441 & 2.863 & 0.036 & yes \\
\hline Comfortable & 3,441 & 2.977 & 0.031 & yes \\
\hline Warm & 3,441 & 4.881 & 0.002 & yes \\
\hline Serene & 3,441 & 3.495 & 0.016 & yes \\
\hline Reassuring & 3,441 & 2.886 & 0.022 & yes \\
\hline Revitalizing & 3,441 & 3.365 & 0.019 & yes \\
\hline Feel in control & 3,441 & 5.154 & 0.002 & yes \\
\hline
\end{tabular}

Source: analysis result (2019) 
Character Scale's result indicates six items shown significant differences in relation to length of stay of respondents in Kota Bharu and scheduled to visit Kota Bharu Cultural Heritage Zone, 'peaceful' (f $(3,441)=6.797, p<0.05)$, 'harmonious' ( $f$ $(3,441)=4.133, p<0.05)$, 'balanced' (f $(3,441)=6.027, \mathrm{p}<0.05)$, 'simple' $(\mathrm{f}(3,441)$ $=3.240, \quad \mathrm{p}<0.05)$, 'spacious' (f $(3,441)$ $=3.947, \quad \mathrm{p}<0.05$ ) and 'open' (f $(3,441)=5.161, p<0.05)$. The other four items shown no significant differences in relation to length of stay of respondents in Kota Bharu and scheduled to visit Kota Bharu Cultural Heritage Zone, 'clean' (f $(3,441)=2.111, \quad p>0.05)$, 'alive (f $(3,441)=1.308, \quad p>0.05)$, 'distinctive' (f $(3,441)=2.345, \quad p>0.05)$ and 'wellmaintained' ( $f(3,441)=2.512, p>0.05$ ). The sense of place referring to the Kota Bharu Cultural Heritage Zone character does influence the tourist to stay longer in the zone.

Inherent Socio-cultural Scale's result indicates all six items of the scale items shown significant differences in the length of stay of respondents. 'authentic' (f $(3,441)=2.831, p<0.05)$,' has the spirit of people' (f $(3,441)=3.050, p<0.05)$,' feel a sense of history' (f $(3,441)=3.378$, $\mathrm{p}<0.05$ ),' historical' (f $(3,441)=4.239$, $\mathrm{p}<0.05)$,' fits within the larger context of Kota Bharu' (f $(3,441)=2.160, p<0.05$ ) and' support the function of Kota Bharu' (f $(3,441)=3.201, p<0.05)$. The sense of place referring to inherent socio-cultural in Kota Bharu Cultural Heritage Zone influences the tourist's decision to stay longer in the zone.

Transactional Socio-cultural Scale's result indicates all six items shown significant differences to the length of stay of respondents in Kota Bharu Cultural Heritage Zone. 'feel part of the community' (f $(3,441)=5.316, p<0.05)$,' offers a sense of belonging' ( $f(3,441)=4.180, p<0.05)$,' provide opportunities for interaction with others' (f $(3,441)=4.009, \mathrm{p}<0.05)$,' civility' (f $(3,441)=4.115, \quad p<0.05$ ),' generates respect for the individual' (f $(2,442)$ $=5.116, \mathrm{p}<0.05)$ and' has a distinct energy' (f $(3,441)=5.316, p<0.05$ ). The sense of place referring to transactional sociocultural in Kota Bharu Cultural Heritage Zone influences the tourist's decision to stay longer in the zone.

Significant scale's result indicates all four items shown significant differences to the length of stay in Kota Bharu Cultural Heritage Zone,' 'meaningful' (f $(3,441)$ $=4.567, \quad \mathrm{p}<0.05)$, ' significant' (f $(3,441)$ $=4.549, \quad p<0.05)$,' interesting' ( $f(3,441)$ $=3.446, p<0.05)$ and' valuable' (f $(3,441)$ $=3.394, \quad \mathrm{p}<0.05$. The sense of place referring to significance in the Kota Bharu Cultural Heritage Zone influences the tourist's decision to stay longer in the zone.

Memory Scale's result indicates three items shown significant differences to the length of stay of respondents in Kota Bharu Cultural Heritage Zone. 'familiar' (f $(3,441)=3.079, p<0.05)$, 'feel a sense of connection' ( $\mathrm{f}(3,441)=3.188, \mathrm{p}<0.05)$, and 'feel a sense of nostalgia' ( $f(3,441)=3.066$, $\mathrm{p}<0.05)$. The other three items showed no significant differences to the length of stay of respondents, which is 'well-known' (f $(3,441)=1.894, p>0.05)$, 'memorable' (f $(3,441)=1.433, p>0.05)$, and 'feel like I know it well' (f $(3,441)=2.460, p>0.05$ ). The sense of place referring to memory in the Kota Bharu Cultural Heritage Zone does not influence the tourist's decision to stay longer in the zone.

\section{Overall tourist perception on the sense of place}

Respondents were also asked about their overall level of sense of place regarding their length of stay in Kota Bharu and scheduled to visit Kota Bharu Cultural 
Heritage Zone. The results using One-Way ANOVA is illustrated in table 2.

Table 2. One-way ANOVA analysis on the overall sense of place

\begin{tabular}{ccccc}
\hline $\begin{array}{c}\text { Dependent } \\
\text { Variables }\end{array}$ & df & F & $\begin{array}{c}\text { sig, } \\
\text { value }\end{array}$ & Sig. \\
\hline Length of Stay & 4,440 & 2.877 & 0.023 & yes \\
\hline
\end{tabular}

Source: analysis result (2019)

The result of ANOVA analysis, which to find respondent's overall sense of place level significant differences to the length of stay of respondents in Kota Bharu and scheduled to visit Kota Bharu Cultural Heritage Zone, shown significant differences, $(F(4,440)=2.877, p<0.05)$. The sense of place in the Kota Bharu Cultural Heritage Zone influences the tourist's decision to stay longer in the zone.

The results show that the sense of place of Kota Bharu Cultural Heritage Zone does influence tourists to stay longer in the zone. It is parallel with the previous research where the length of stay affects the high value of the sense of place, and length of stay relates to the attachment of tourism product as mentioned by Smaldone (2007). From 10 scales of the length of stay, eight scales influence the tourist decision to stay longer in the heritage zone with a great sense of place.

\section{Conclusion}

This study has identified and explored the gap in tourism research in terms of place relationship with tourist behaviors, particularly tourist length of stay in the heritage site. It helps the government and tourism players in planning attractions for tourists hence sustaining the area in terms of social and economic factors. The OneWay ANOVA analysis between the sense of place items with the respondent's length of stay may help the tourism business operators identify a specific area for improving and enhancing. The study also reveals that heritage tourism is significantly connected with the sense of place. This because the authenticity, historical values, distinctive, harmonious, well-maintained, and clean are part of the sense of place scale. Therefore, to improve the tourism industry, a sense of place is one of the essential components that should not be neglected. Furthermore, this study contributes to the body of knowledge by providing empirical evidence for academic development needs in the future.

\section{Authors statement}

With this, the authors state that this study is free from conflicts of interest with any party.

\section{Acknowledgment}

The authors would like to thank all those who have supported this research.

\section{References}

Ahmed, S. (2009). Methods in Sample Survey: Simple Random Sampling Systematic Sampling [Class material]. http://ocw.jhsph.edu/courses/Stat MethodsForSampleSurveys/PDFs/

Alén, E., Nicolau, J. L., Losada, N., \& Domínguez, T. (2014). Determinant factors of senior tourists' length of stay. Annals of Tourism Research, 49, 19-32.

https://doi.org/10.1016/j.annals.2 014.08 .002

Alvi, M. (2016). A Manual for Selecting Sampling Techniques in Research. Munich University Library. https://mpra.ub.unimuenchen.de/70218/

Barros, C. P., \& Machado, L. P. (2010). The length of stay in tourism. Annals of Tourism Research, 37(3), 692-706. https://doi.org/10.1016/j.annals.2 009.12 .005

Botes, V. L. (2009). The perception of the skills required and displayed by management accountants to meet future challenges [Thesis, University 
of South Africa].

http://uir.unisa.ac.za/handle/1050 $0 / 1935$

Bott, S. E. (2000). The development of psychometric scales to measure sense of place. Colorado State University.

Counted, V. (2019). The Role of Spirituality in Promoting Sense of Place Among Foreigners of African Background in the Netherlands. Ecopsychology, 11(2), 101-109. https://doi.org/10.1089/eco.2018. 0070

de Menezes, A. G., Moniz, A., \& Vieira, J. C. (2008). The determinants of length of stay of tourists in the Azores. Tourism Economics. https://doi.org/10.5367/00000000 8783554866

Frerichs, R. R. (2008). Simple Random Sampling [Course material]. Rapid Survey Course. http://www.ph.ucla.edu/epi/rapids urveys/RScourse/RSrapidsurveys.h tml

Hauge, Å. L. (2007). Identity and Place: A Critical Comparison of Three Identity Theories. Architectural Science Review, 50(1), 44-51. https://doi.org/10.3763/asre.2007. 5007

Idrus, A., Khamidi, F., \& Sodangi, M. (2010). Maintenance Management Framework for Conservation of Heritage Buildings in Malaysia. Modern Applied Science, 4(11), p66. https://doi.org/10.5539/mas.v4n1 $1 \mathrm{p} 66$

Kazuzuru, B. (2014). Determinants of tourist length of stay in Tanzania. International Journal of Business and Social Science, 5(9), 11. http://ijbssnet.com/journals/Vol_5 _No_9_1_August_2014/
Kelantan Tourism Information Centre. (2017). Kelantan Tourist Arrival Statistic.

McCunn, L. J., \& Gifford, R. (2014). Interrelations between sense of place, organizational commitment, and green neighborhoods. Cities, 41, 20-29.

https://doi.org/10.1016/j.cities.20 14.04.008

Mora, R.-J., \& Kloet, B. (2010). Digital Forensic Sampling. SANS Digital Forensics and Incident Response Blog. https://www.sans.org/blog/digitalforensic-sampling/

Pretty, G. H., Chipuer, H. M., \& Bramston, P. (2003). Sense of place amongst adolescents and adults in two rural Australian towns: The discriminating features of place attachment, sense of community and place dependence in relation to place identity. Journal of Environmental Psychology, 23(3), 273-287.

https://doi.org/10.1016/S02724944(02)00079-8

Raadik-Cottrell, J. (2010). Cultural memory and place identity: Creating place experience [Dissertation]. Colorado State University.

Santos, G. E. de O., Ramos, V., \& ReyMaquieira, J. (2014). Length of stay at multiple destinations of tourism trips in brazil: Journal of Travel Research, 54(6), 788-800. https://doi.org/10.1177/00472875 14532370

Shalab. (2019). Introduction to Sampling Theory. Indian Institute of Technology Kanpur. http://home.iitk.ac.in/ shalab/cou rse432.htm

Smaldone, D. (2007). The role of time in place attachment. Proceedings of the 
2006 Northeastern Recreation

Research Symposium, 14, 57-56. https://www.fs.usda.gov/treesearc h/pubs/12653

Tan, S.-K., Tan, S.-H., Kok, Y.-S., \& Choon, S.W. (2018). Sense of place and sustainability of intangible cultural heritage - The case of George Town and Melaka. Tourism Management, 67 , 376-387. https://doi.org/10.1016/j.tourman. 2018.02.012

Thrane, C., \& Farstad, E. (2012). Tourists' Length of Stay: The Case of
International Summer Visitors to Norway: Tourism Economics, 18(5), 1069-1082. https://doi.org/10.5367/te.2012.0 158

\section{Authors Contribution}

Nik Mohamad Aizat Nik Mohd Adib contributed to conceptualization, data collection, investigation, and original draft writing.

Syakir Amir Ab. Rahman contributed to methodology, formal analysis, validation, writing - review, and editing 
Appendix 1. Respondents socio-demographic profile

\begin{tabular}{|c|c|c|c|c|c|c|c|}
\hline \multirow[t]{2}{*}{ Variable } & \multirow[t]{2}{*}{ Components } & \multicolumn{2}{|c|}{ Domestic } & \multicolumn{2}{|c|}{ International } & \multicolumn{2}{|c|}{ Total } \\
\hline & & Unit & $\%$ & Unit & $\%$ & Unit & $\%$ \\
\hline \multirow{2}{*}{ Gender } & male & 171 & 38.4 & 20 & 4.5 & 191 & 42.9 \\
\hline & female & 233 & 52.4 & 21 & 4.7 & 254 & 57.1 \\
\hline \multirow[t]{6}{*}{ Age } & $15-20$ & 150 & 33.7 & 2 & 0.4 & 152 & 34.2 \\
\hline & $21-30$ & 160 & 36.0 & 26 & 5.8 & 186 & 41.8 \\
\hline & $31-40$ & 57 & 12.8 & 10 & 2.2 & 67 & 15.1 \\
\hline & $41-50$ & 25 & 5.6 & 3 & 0.7 & 28 & 6.3 \\
\hline & $51-60$ & 10 & 2.2 & 0 & 0.0 & 10 & 2.2 \\
\hline & $61-70$ & 2 & 0.4 & 0 & 0.0 & 2 & 0.4 \\
\hline \multirow[t]{4}{*}{ Marital status } & single & 272 & 61.1 & 22 & 4.9 & 294 & 66.1 \\
\hline & married & 121 & 27.2 & 13 & 2.9 & 134 & 30.1 \\
\hline & widowed & 6 & 1.3 & 1 & 0.2 & 7 & 1.6 \\
\hline & divorced & 5 & 1.1 & 5 & 1.1 & 10 & 2.2 \\
\hline \multirow[t]{5}{*}{ Occupation } & student & 189 & 42.5 & 10 & 2.2 & 199 & 44.7 \\
\hline & government servant & 129 & 29.0 & 9 & 2.0 & 138 & 31.0 \\
\hline & private & 73 & 16.4 & 16 & 3.6 & 89 & 20.0 \\
\hline & pensioner & 4 & 0.9 & 0 & 0.0 & 4 & 0.9 \\
\hline & others / unemployed & 9 & 2.0 & 6 & 1.3 & 15 & 3.4 \\
\hline \multirow[t]{8}{*}{ Education } & SPM/O-level & 61 & 13.7 & 1 & 0.2 & 62 & 13.9 \\
\hline & $\begin{array}{l}\text { STPM/matriculation/ } \\
\text { A-level }\end{array}$ & 13 & 2.9 & 0 & 0.0 & 13 & 2.9 \\
\hline & certificate & 17 & 3.8 & 3 & 0.7 & 20 & 4.5 \\
\hline & diploma & 182 & 40.9 & 8 & 1.8 & 190 & 42.7 \\
\hline & bachelor degree & 108 & 24.3 & 13 & 2.9 & 121 & 27.2 \\
\hline & master degree & 14 & 3.1 & 9 & 2.0 & 23 & 5.2 \\
\hline & $\mathrm{PhD}$ & 8 & 1.8 & 6 & 1.3 & 14 & 3.1 \\
\hline & others & 1 & 0.2 & 1 & 0.2 & 2 & 0.4 \\
\hline Origins & & 404 & 90.8 & 41 & 9.2 & 445 & 100 \\
\hline
\end{tabular}

Appendix 2. Respondents trip profile

\begin{tabular}{llcccccc}
\hline \multirow{2}{*}{ Variables } & \multirow{2}{*}{ Components } & \multicolumn{2}{c}{ Domestic } & \multicolumn{2}{c}{ International } & \multicolumn{2}{c}{ Total } \\
& & Unit & $\mathbf{\%}$ & Unit & \% & Unit & \% \\
\hline \multirow{2}{*}{ First Visit } & yes & 143 & 32.1 & 34 & 7.6 & 177 & 39.8 \\
& no & 261 & 58.7 & 7 & 1.6 & 268 & 60.2 \\
\hline Length & 1 day & 45 & 10.1 & 0 & 0.0 & 45 & 10.1 \\
of stay & 2-4 days & 227 & 51.0 & 12 & 2.7 & 239 & 53.7 \\
(LOS) & 5-7 days & 97 & 21.8 & 15 & 3.4 & 112 & 25.2 \\
& 8 or more days & 35 & 7.9 & 14 & 3.1 & 49 & 11.0 \\
\hline
\end{tabular}

